\title{
Investment management education: \\ Is there a gap between the perceptions of academics and of practitioners?
}

\author{
HP Wolmarans \\ Department of Accounting and Finance \\ University of Pretoria
}

\begin{abstract}
In recent years, investment management education has become increasingly relevant. As a result of this development, it is essential that various role players should be consulted to ensure that investment management is taught in line with practitioners' requirements. The South African Qualifications Authority also specifies that educators and practitioners should collaborate to maintain relevance in all fields of education. The importance of various areas in investment management was investigated. This article compares the ranking of these areas in terms of their importance as perceived by academics and practitioners. The study being reported also aimed to determine whether gaps exist between the areas that academics regard to be important and the areas that practitioners regard as such.

Areas that are generally regarded to be most important include asset allocation, fundamental analysis and the measurement of risk and return. Areas that are regarded to be least important include arts, antiques and other hard assets; rights and capitalisation issues; and real estate. Areas in need of research include the measurement of risk and return; asset allocation; derivatives; and global markets and instruments. The findings of this study could have a significant impact on the provision of relevant training for South African investment specialists.
\end{abstract}

Key words

Investment management education

$S A Q A$ requirements

Relevant areas in investment management 


\section{Introduction}

Academics are often accused of 'living in an ivory tower' and of not focusing on the needs of the market when educating students in various disciplines. While Bosch, Radder, Tait and Venter (1994) regard finance as one of the most important disciplines in the training of general managers, Cooley and Heck (1996:1) point out that the discipline of investment is closely related to that of finance. Because investment analysts and portfolio managers are increasingly regarded to fulfil a pivotal role in the creation and retention of wealth, it is important that investment management education should be relevant. Furthermore, the South African Qualifications Authority (SAQA) Act No. 58 of 1995 recommends amongst other things that academics and practitioners should consult regularly to ensure that education in all fields is relevant and focused on the needs of industry (Government Gazette 1995).

The study reported in this article investigated the importance of various areas in investment management. This article compares the ranking of these areas in terms of the importance accorded to them by academics and by practitioners. It also attempts to determine whether there are gaps between the areas that academics regard as important and the areas that practitioners regard as such.

Section two of this article presents a survey of the relevant literature. Section three lists the hypotheses to be tested and section four provides details of the empirical investigation that was undertaken. Section five considers how the various areas in investment were rated, while section six enquires which areas are perceived to be of greater importance. Section seven considers which areas are less important, and section eight asks which areas require more research. Section nine deals with areas that require more attention than they are currently receiving in the training of investment specialists. In section ten, conclusions are drawn and areas for further research identified.

\section{$2 \quad$ Literature survey}

The management of knowledge has become increasingly important over the past few years. Knowledge has become the critical resource for gaining a competitive advantage (Drucker 1992:95). The successful management of knowledge in organisations entails knowing what the knowledge requirements of clients are as well as mastering the complexities of the transfer of knowledge between knowledge workers and clients (Bagrain 1997:21). If the tertiary education system is viewed as comprising knowledge enterprises (universities) that have many knowledge workers (academics) that strive to satisfy the needs of its clients (practitioners in industry) by delivering knowledge products (graduates), it is necessary to examine the gaps that may exist between 
the importance of specific elements of the knowledge that is required and the knowledge that is delivered.

The South Africa Qualifications Authority (SAQA) requires that each of its Education and Training Quality Assurance bodies (ETQA's) should focus on serving the needs of a sector of industry (SAQA 1998:15). This focus entails that regular communication should be maintained with practitioners in order to ensure that educators are aware of the needs of the sector and provide learners with the skills and knowledge that they require.

Brand (1996:81) states that facilitators in management education in South Africa should maintain communication with industry to ensure that education continues to fulfil the needs of industry. Any gap that may exist between what academics regard to be important and what practitioners regard to be important should therefore be closely monitored. While Wolmarans (1999:523) investigated the existence of such gaps in respect of financial management, Van Rooyen (1996:88) investigated gaps in respect of financial risk management. In an extensive literature survey, no studies were identified that focused exclusively on potential gaps between that academics on the one hand and practitioners on the other regard to be important in investment management education.

The financial and investment education literature often contains a debate on what is considered to be a proper balance between theory and practice to ensure the relevance of a programme. Davis (1996:26) calls for more interaction between academics and the business community. Simpson (1997:34) argues for a change in the behaviour of all parties in the financial education process, including administrators, faculty, students, and the business community, with the aim of increasing the relevance of all academic programmes. He asserts that "relevance is the basis for value creation in the educational process" and warns that irrelevant programmes may not survive. Charlton (1998:69) reviews the benefits of having restructured an undergraduate programme in order to fulfil the needs of industry to a greater extent. These benefits include improved student learning, increased contact with the professional community and better job placements for students.

\section{Hypotheses to be tested}

In pursuance of the statement of the problem and the literature survey, the following hypotheses were tested to address the stated problem:

Hypothesis 1: There is no difference between the views of academics and of practitioners regarding the importance of all the areas in investment. 
Hypothesis 2: Academics regard the various areas in investment to be of equal importance.

Hypothesis 3: Practitioners regard the various areas in investment to be of equal importance.

Hypothesis 4: The areas that academics regard to be most important in investment are the same as the areas that practitioner regard to be most important.

Hypothesis 5: The areas that academics regard as the least important in investment are the same as the areas that practitioners regard as such.

Hypothesis 6: Academics and practitioners agree on the areas in investment management that are most in need of research.

Hypothesis 7: Practitioners believe that there are some areas in the education of investment specialists that should receive more attention than they are currently receiving.

The findings of this study could be of value to a wide spectrum of role players. Anyone who has even a superficial interest in investment would be interested to know which areas have been found to be most useful. If there are significant differences between the ratings of academics and the ratings of practitioners of the various areas in investment, the differences could be of interest to both these groups. Academics should bear future training needs in mind and practitioners should know where inputs should be made if future academic training is to address the problems that they experience.

An evaluation of the areas in investment that both academics and practitioners regard to be most important for an investment practitioner, as well as of the areas that are regarded to be of less importance, may be of value to the designers of the courses for the training of investment managers. In addition, designers of courses need to know about the possible areas that, in the opinion of practitioners, deserve more attention than they are currently receiving in the training of investment practitioners. Finally, an analysis of the areas that both practitioners and academics consider to be in need of research will probably have an affect on the nature of future research.

\section{$4 \quad$ Empirical investigation}

In compiling a questionnaire for this investigation, the general structure of the areas that Bodie, Kane and Marcus (1993) compiled, was taken as a point of departure. The list of areas to be included was adjusted after other sources (Bodie, Kane and Marcus 2001; Jones 2000; Brummer 
and Rademeyer 1982) and various experts in the field of investment management had been consulted. It was decided to use a questionnaire rather than to undertake a telephonic interview, because respondents have limited time available and this method would enable them to complete and return the questionnaire at their convenience. The aim of the questionnaire was to enable the respondents to rate all the areas that are generally regarded to be important in investment. The respondents also had the option of listing and rating two areas that, in their opinion, should have been included in the list.

A pilot study was undertaken and the questionnaire adjusted. The same questionnaire was used in both subsequent studies. Respondents were requested to rate various areas in investment in terms of a 10-point scale in the order of their importance for a South African investment practitioner. A 10-point scale was used, because it permitted more variability in answers than either a five-point scale or a seven-point scale. Thereafter, respondents were requested to indicate which areas in investment they regarded to be in need of more research with a view to enhancing the value of investment as a discipline for South African practitioners. All the respondents were informed that they would be given a summary of the research findings upon the completion of the project, if they were interested in receiving it.

In the first survey, members of SAFA (the South African Finance Association) were telephoned to determine who taught courses on investment at the South African universities. Because there were only a few academics in the field and it was necessary that they would participate, the 31 targeted academics were telephoned to obtain their co-operation. These academics were requested to complete a two-page questionnaire, which was faxed to them. A $100 \%$ response rate was achieved, probably because of the personal communication with the respondents. Personal communication was established with the lecturers at all the major South African tertiary education institutions that offer investment education. The sample may therefore be regarded to be representative of academics in the South African investment community.

In the second survey, 247 questionnaires were posted to investment institutions that were registered with the Financial Services Board (FSB). This registration was regarded to be the best available data set of institutions that were officially involved in investments. Respondents were requested to complete the questionnaire, which was similar to the one discussed above, but contained one additional question. The practitioners were requested to indicate which aspect(s) of investment, in their opinion, deserved more attention than they were currently receiving in the training of investment practitioners. 
Only 46 of the practitioners completed the questionnaire, which represents a response rate of $18,6 \%$. Considering the fact that no personal communication was established with the respondents, the response rate compares favourably with the response rate of $10-15 \%$ that is usually achieved in postal surveys (Hague 1995:20). Because the address list of the FSB was used, this sample can be regarded as being representative of the practitioners in the South African investment community.

Perhaps the major limitation of this investigation is the nature of the practitioners that were invited to participate. It could be argued that there could be many fund managers that manage high-value portfolios that were not included. It is indeed true that, if a large insurance company appeared on the list of registered fund managers of the Financial Services Board, only one questionnaire was sent to the contact person listed, although the insurance company concerned could have had many capable fund managers. No provision was made for the value of the funds managed by such an institution and no weighting was awarded to the answers of individual respondents.

Another limitation of this investigation is that, as a result of the nature of the respondents, investment in shares appears to have been given greater prominence than investment in real estate. It is, however, a wellknown fact that large fund-managing institutions, such as insurance companies and pension funds, invest heavily in real estate. The importance of investment in real estate and other types of hard assets was therefore probably not given due recognition in the study.

\section{How were the areas in investment rated?}

Hypothesis 1 states that there is no difference between academics and practitioners regarding the importance they accord to various areas in investment. Table 1 presents the results of the rankings given by the two groups of respondents in the surveys. The results are presented in the form of means and standard deviations. Whereas significant differences were found, the levels of significance are indicated as highly significant (at $1 \%)$, moderately significant $(5 \%)$ or merely as significant $(10 \%)$. 
Table 1: Means and standard deviations of the ranking of areas by academics $(n=31)$ and by practitioners $(n=46)$

\begin{tabular}{|c|c|c|c|c|c|c|c|}
\hline \multirow[t]{2}{*}{ No. } & \multirow[t]{2}{*}{ Area } & \multicolumn{2}{|c|}{ Academics } & \multicolumn{2}{|c|}{ Practitioners } & \multirow{2}{*}{$\begin{array}{c}\mathrm{p}- \\
\text { value }\end{array}$} & \multirow{2}{*}{$\begin{array}{l}\text { Signifi- } \\
\text { cance }\end{array}$} \\
\hline & & Mean & SD & Mean & SD & & \\
\hline Q1 & The financial system & 5,74 & 2,05 & 6,85 & 1,97 & 0,020 & ** \\
\hline Q2 & The investment process & 7,16 & 2,25 & 7,87 & 2,01 & 0,152 & \\
\hline Q3 & Money market instruments & 7,03 & 1,58 & 6,89 & 1,96 & 0,739 & \\
\hline Q4 & Capital market instruments & 7,42 & 1,39 & 7,52 & 1,35 & 0,747 & \\
\hline Q5 & Measuring risk and return & 8,71 & 1,42 & 8,43 & 1,22 & 0,368 & \\
\hline Q6 & Asset allocation & 8,55 & 1,67 & 8,22 & 1,76 & 0,412 & \\
\hline Q7 & $\begin{array}{l}\text { The Capital Asset Pricing } \\
\text { Model }\end{array}$ & 7,56 & 1,77 & 5,93 & 2,45 & 0,002 & *** \\
\hline Q8 & Arbitrage pricing theory & 6,23 & 2,14 & 5,41 & 2,31 & 0,124 & \\
\hline Q9 & $\begin{array}{l}\text { Portfolio performance } \\
\text { evaluation }\end{array}$ & 8,23 & 1,20 & 7,76 & 1,69 & 0,211 & \\
\hline Q10 & Fundamental analysis & 8,10 & 1,64 & 8,09 & 1,40 & 0,978 & \\
\hline Q11 & Technical analysis & 6,19 & 1,80 & 5,61 & 2,50 & 0,266 & \\
\hline Q12 & Macroeconomic analysis & 6,97 & 1,72 & 7,22 & 1,58 & 0,513 & \\
\hline Q13 & Sector and industry analysis & 6,97 & 1,87 & 7,59 & 1,31 & 0,091 & * \\
\hline Q14 & Financial statement analysis & 6,74 & 1,98 & 7,33 & 1,80 & 0,184 & \\
\hline Q15 & Market efficiency & 6,16 & 2,00 & 6,43 & 1,94 & 0,551 & \\
\hline Q16 & Bond fundamentals & 7,19 & 1,89 & 7,17 & 1,74 & 0,963 & \\
\hline Q17 & Interest rates and yield curves & 6,94 & 2,14 & 7,26 & 1,95 & 0,492 & \\
\hline Q18 & Duration and immunisation & 6,35 & 2,53 & 6,24 & 2,04 & 0,825 & \\
\hline Q19 & Derivatives & 7,48 & 1,75 & 6,49 & 2,66 & 0,069 & * \\
\hline Q20 & Financial risk management & 7,16 & 1,90 & 8,11 & 1,46 & 0,016 & ** \\
\hline Q21 & $\begin{array}{l}\text { Rights and capitalisation } \\
\text { issues }\end{array}$ & 5,61 & 1,89 & 5,41 & 2,11 & 0,623 & \\
\hline Q22 & $\begin{array}{l}\text { Global markets and } \\
\text { instruments }\end{array}$ & 7,16 & 1,42 & 8,26 & 1,63 & 0,003 & *** \\
\hline Q23 & Retirement and pension funds & 6,42 & 1,91 & 7,41 & 1,94 & 0,030 & ** \\
\hline Q24 & $\begin{array}{l}\text { Management of investment } \\
\text { companies }\end{array}$ & 5,26 & 1,88 & 5,85 & 2,17 & 0,222 & \\
\hline Q25 & Real estate & 4,52 & 1,69 & 4,70 & 2,23 & 0,705 & \\
\hline \multirow[t]{2}{*}{ Q26 } & $\begin{array}{l}\text { Arts, antiques and other hard } \\
\text { assets }\end{array}$ & 3,06 & 1,75 & 2,39 & 1,90 & 0,120 & \\
\hline & $\begin{array}{l}\text { Levels of significance: } \\
{ }^{* * *} 1 \% ;{ }^{* *} 5 \% ;{ }^{*} 10 \%\end{array}$ & & & & & & \\
\hline
\end{tabular}

A multivariate analysis of variance (MANOVA) was performed by means of the SAS (Statistical Analysis Systems) programme on the mainframe at the University of Pretoria to determine whether any comparable elements of the two vectors of means differed significantly, considering the variance and the dependency of response (SAS Institute 1985). Because provision was made for possible correlation between questions, this procedure is more appropriate than the performing of 26 T-tests on the data. (If the T-tests had been performed, it would have capitalised on the level of significance, which would have increased the possibility of a Type II-error.) 
It is evident from table 1 that the mean ratings differ significantly for seven of the 26 areas. The areas that practitioners perceived to be significantly more important than academics did, are the financial system (Q1); sector and industry analysis (Q13); financial risk analysis (Q20); global markets and instruments (Q22); and retirement and pension funds (Q23). This finding could imply that these areas should be given more weight in training courses than is the case at present.

It is somewhat surprising that there is a large measure of similarity in the rankings that the two groups of respondents accorded to many areas. These areas include fundamental analysis (Q10), bond fundamentals (Q16) and duration and immunisation (Q18). The fact that these ratings are numerically very similar, indicates that the one group of respondents did not consistently rate some areas higher than the other group. (If such differences in ratings had occurred, there might have been a need for a scale transformation in which only the relative ratings of the two groups could be compared.)

The academics rated the following areas as being significantly more important than did the practitioners: the Capital Asset Pricing Model (Q7) and derivatives (Q19). This could mean that these areas are currently receiving more attention in academic courses than practitioners believe to be necessary. In fact, there appears to be at least some significant differences in respect of the perceived importance of the various areas in investment as perceived by practitioners on the one hand and by academics on the other. Hypothesis 1 must therefore be rejected.

\section{Which areas are perceived to be more important than other areas?}

Hypothesis 2 states that the academics regard the various areas in investment to be equally important. The most appropriate test in this regard is the Waller-Duncan k-ratio t-test, which is performed on all main-effect means (SAS Institute 1985:118, 487). If a vector of answers were investigated (for instance, the academics' responses), this test could determine whether there were any significant differences between the elements of the vector. The test was performed by means of SAS on each of the data sets to determine whether respondents had, on average, rated questions 1 to 26 in a similar manner. The results of the analysis of the academics' ratings are set out in table 2, from which it is clear that the means with the same letter under "Grouping" do not differ significantly at $p=0.05$. This finding means that, for example in table 2 , the average rating of the measurement of risk and return (Q5) does not differ significantly from the average rating of fundamental analysis (Q10), but it does differ significantly from the rating of the Capital Asset Pricing Model (Q7). It can be concluded from table 2 that the academics regard some areas in investment to be significantly more important than others. Hypothesis 2 is therefore rejected. 
Table 2: Ranking of areas by the academics $(n=31)$

\begin{tabular}{|l|l|l|c|l|l|l|l|l|l|}
\hline Ranking & No. & Area & \multicolumn{3}{|l|}{ Mean } & \multicolumn{5}{|c|}{ Grouping } \\
\hline 1 & Q5 & Measurement of risk and return & 8,71 & A & & & & & \\
\hline 2 & Q6 & Asset allocation & 8,55 & A & & & & & \\
\hline 3 & Q9 & Portfolio performance evaluation & 8,23 & A & B & & & & \\
\hline 4 & Q10 & Fundamental analysis & 8,10 & A & B & C & & & \\
\hline 5 & Q7 & The Capital Asset Pricing Model & 7,58 & D & B & C & & & \\
\hline 6 & Q19 & Derivatives & 7,48 & D & B & C & E & & \\
\hline 7 & Q4 & Capital market instruments & 7,42 & D & & C & E & & \\
\hline 8 & Q16 & Bond fundamentals & 7,19 & D & & & E & & \\
\hline 9 & Q2 & The investment process & 7,16 & D & F & & E & & \\
\hline 10 & Q20 & Financial risk management & 7,16 & D & F & & E & & \\
\hline 11 & Q22 & Global markets and instruments & 7,15 & D & F & & E & & \\
\hline 12 & Q3 & Money market instruments & 7,03 & D & F & G & E & & \\
\hline 13 & Q13 & Sector and industry analysis & 6,97 & D & F & G & E & H & \\
\hline 14 & Q12 & Macroeconomic analysis & 6,97 & D & F & G & E & H & \\
\hline 15 & Q17 & Interest rates and yield curves & 6,94 & D & F & G & E & H & I \\
\hline 16 & Q14 & Financial statement analysis & 6,74 & J & F & G & E & H & I \\
\hline 17 & Q23 & Retirement and pension funds & 6,42 & J & F & G & K & H & I \\
\hline 18 & Q18 & Duration and immunisation & 6,35 & J & L & G & K & H & I \\
\hline 19 & Q8 & Arbitrage pricing theory & 6,23 & J & L & & K & H & I \\
\hline 20 & Q11 & Technical analysis & 6,19 & J & L & & K & & I \\
\hline 21 & Q15 & Market efficiency & 5,74 & M & L & & K & & \\
\hline 22 & Q1 & The financial system & L & & K & & \\
\hline 23 & Q21 & Rights and capitalisation issues & 3,06 & M & L & & & & \\
\hline 24 & Q24 & Management of investment companies & & & & \\
\hline 25 & Q25 & Real estate & & & & & \\
\hline 26 & Q26 & Arts, antiques and other hard assets & 3,06 & & \\
\hline
\end{tabular}

Hypothesis 3 states that the practitioners perceive the various areas in investment to be of equal importance. Table 3 contains the results of the practitioners' ratings. Once again, the means that have the same letter do not differ significantly. As in respect of the academics' ratings in table 2 , it can be concluded from table 3 that the practitioners regard some areas in investment to be significantly more important than others. Hypothesis 3 must therefore be rejected. 
Table 3: Ranking of areas by the practitioners $(n=46)$

\begin{tabular}{|c|c|c|c|c|c|c|c|c|}
\hline \multirow{2}{*}{$\begin{array}{l}\text { Ranking } \\
1 \\
\end{array}$} & \multirow{2}{*}{$\begin{array}{l}\text { No. } \\
\text { Q5 } \\
\end{array}$} & \multirow{2}{*}{$\begin{array}{l}\text { Area } \\
\text { Measurement of risk and return }\end{array}$} & \multirow{2}{*}{$\begin{array}{r}\text { Mean } \\
8,43 \\
\end{array}$} & \multicolumn{5}{|c|}{ Grouping } \\
\hline & & & & $\mathrm{A}$ & & & & \\
\hline 2 & Q22 & Global markets and instruments & 8,26 & A & B & & & \\
\hline 3 & Q6 & Asset allocation & 8,22 & $\mathrm{~A}$ & $\mathrm{~B}$ & $\mathrm{C}$ & & \\
\hline 4 & Q20 & Financial risk management & 8,11 & A & $\mathrm{B}$ & $\mathrm{C}$ & $D$ & \\
\hline 5 & Q10 & Fundamental analysis & 8,09 & A & $\mathrm{B}$ & $\mathrm{C}$ & $D$ & \\
\hline 6 & Q2 & The investment process & 7,87 & A & $\mathrm{B}$ & $\mathrm{C}$ & $\mathrm{D}$ & $\mathrm{E}$ \\
\hline 7 & Q9 & Portfolio performance evaluation & 7,76 & $\mathrm{~F}$ & $\mathrm{~B}$ & $\mathrm{C}$ & $\mathrm{D}$ & $E$ \\
\hline 8 & Q13 & Sector and industry analysis & 7,59 & $\mathrm{~F}$ & & $\mathrm{C}$ & D & E \\
\hline 9 & Q4 & Capital market instruments & 7,52 & $\mathrm{~F}$ & G & & $\mathrm{D}$ & $\mathrm{E}$ \\
\hline 10 & Q23 & Retirement and pension funds & 7,41 & $\mathrm{~F}$ & $\mathrm{G}$ & $\mathrm{H}$ & & $E$ \\
\hline 11 & Q14 & Financial statement analysis & 7,33 & $\mathrm{~F}$ & $\mathrm{G}$ & $\mathrm{H}$ & & $E$ \\
\hline 12 & Q17 & Interest rates and yield curves & 7,26 & $\mathrm{~F}$ & $\mathrm{G}$ & $\mathrm{H}$ & & $E$ \\
\hline 13 & Q12 & Macroeconomic analysis & 7,22 & $\mathrm{~F}$ & $\mathrm{G}$ & $\mathrm{H}$ & & \\
\hline 14 & Q16 & Bond fundamentals & 7,17 & $\mathrm{~F}$ & $\mathrm{G}$ & $\mathrm{H}$ & & \\
\hline 15 & Q3 & Money market instruments & 6,89 & 1 & $\mathrm{G}$ & $\mathrm{H}$ & & \\
\hline 16 & Q1 & The financial system & 6,85 & 1 & $\mathrm{~J}$ & $\mathrm{H}$ & & \\
\hline 17 & Q19 & Derivatives & 6,48 & $\mathrm{I}$ & $\mathrm{J}$ & $\mathrm{K}$ & & \\
\hline 18 & Q15 & Market efficiency & 6,43 & $\mathrm{I}$ & $\mathrm{J}$ & $\mathrm{K}$ & & \\
\hline 19 & Q18 & Duration and immunisation & 6,24 & $\mathrm{~L}$ & $\mathrm{~J}$ & $\mathrm{~K}$ & & \\
\hline 20 & Q7 & The Capital Asset Pricing Model & 5,93 & $\mathrm{~L}$ & M & $\mathrm{K}$ & & \\
\hline 21 & Q24 & Management of investment companies & 5,85 & $\mathrm{~L}$ & $\mathrm{M}$ & $\mathrm{K}$ & & \\
\hline 22 & Q11 & Technical analysis & 5,61 & $\mathrm{~L}$ & $\mathrm{M}$ & & & \\
\hline 23 & Q8 & Arbitrage pricing theory & 5,41 & & $\mathrm{M}$ & & & \\
\hline 24 & Q21 & Rights and capitalisation issues & 5,41 & & $\mathrm{M}$ & & & \\
\hline 25 & Q25 & Real estate & 4,70 & $\mathrm{~N}$ & & & & \\
\hline 26 & Q26 & Arts, antiques and other hard assets & 2,39 & $\mathrm{O}$ & & & & \\
\hline
\end{tabular}

Hypothesis 4 states that the areas that the academics regard to be most important in investment are the same as the areas that practitioners regard as such. When the areas ranked in the first five places in tables 2 and 3 are compared, it is noteworthy that three of these five areas were considered by both the academics and the practitioners to be important enough to occupy one of the top five places. Therefore both groups of respondents agree that measurement of risk and return (Q5), asset allocation (Q6) and fundamental analysis (Q10) are among the five most important areas. This consensus confirms the importance of the variables termed measurement of risk and return; importance of asset allocation; and fundamental analysis.

In a comparison of the first ten places, more areas are added to the above list, namely the investment process (Q2), capital market instruments (Q4), portfolio performance evaluation (Q9) and financial risk management (Q20). Areas that are notably absent from the first ten 
places accorded by the academics are global markets and instruments (Q22); sector and industry analysis (Q13); and retirement and pension funds (Q23). These areas are among the first ten places accorded by the practitioners. On the other hand, the Capital Asset Pricing Model (Q7), bond fundamentals (Q16) and derivatives (Q19) are among the areas in the first ten places accorded by the academics, but not among the first ten places accorded by the practitioners. This finding confirms the results that are set out in table 1. Although there are similarities between the rankings of the areas by the academics and the practitioners, there are clearly also differences. Hypothesis 4 must therefore be rejected.

\section{Which areas are perceived to be less important than other areas?}

Hypothesis 5 states that the areas that academics regard to be the least important in investment are the same as the areas that practitioners regard to be the least important. When the areas ranked in the last five places in tables 2 and 3 are compared, it is clear that the areas termed rights and capitalisation issues (Q21); real estate (Q25); and arts, antiques and other hard assets (Q26) were regarded by both groups of respondents to be among the least important for a South African investment practitioner.

In a comparison of the last ten positions accorded by both groups, more areas are added to the list of "less important" areas. These areas include arbitrage pricing theory (Q8); technical analysis (Q11); market efficiency (Q15); duration and immunisation (Q18); and management of investment companies (Q24). This finding does not mean that these areas are totally unimportant, but rather that they are less important, at least in a general sense, for a South African investment practitioner. From the Waller grouping in tables 2 and 3 , it can also be seen that some of these areas were rated as significantly less important than many other areas. Although there are similarities between the rankings of the areas regarded by the academics and the practitioners to be less important, there are differences between these rankings. Hypothesis 5 must therefore be rejected.

\section{Which areas in investment are perceived to be in need of more research?}

Hypothesis 6 postulates that the academics and the practitioners agree on the areas in investment management in respect of which there is the greatest need for research. Respondents were requested to list four areas in respect of which, in their opinion, there is a need for more research in order to enhance the value of the discipline for South African investment practitioners. The results of this analysis are provided in table 
5 and 6 . It could be said that each respondent had four votes to indicate the areas that he/she considered to be in need more research. The votes cast by the academics indicates that the top ten areas they considered to be in need of more research received $80.5 \%$ of the votes, whereas the comparable figure for the practitioners was $75.5 \%$.

Table 4: The ten areas most in need of research as ranked by academics $(n=31)$

\begin{tabular}{|l|l|l|c|}
\hline No. & & Area & $\%$ \\
\hline 1 & Q9 & Portfolio performance evaluation & 14,2 \\
\hline 2 & Q22 & Global markets and instruments & 11,5 \\
\hline 3 & Q6 & Asset allocation & 10,6 \\
\hline 4 & Q19 & Derivatives & 8,8 \\
\hline 5 & Q5 & Measurement of risk and return & 7,1 \\
\hline 6 & Q15 & Market efficiency & 6,2 \\
\hline 7 & Q20 & Financial risk management & 6,2 \\
\hline 8 & Q8 & Arbitrage pricing theory & 5,3 \\
\hline 9 & Q10 & Fundamental analysis & 5,3 \\
\hline 10 & Q23 & Retirement and pension funds & 5,3 \\
\hline & & Total & $\mathbf{8 0 . 5}$ \\
\hline
\end{tabular}

Table 5: The ten areas most in need of research as ranked by practitioners $(n=46)$

\begin{tabular}{|l|l|l|r|}
\hline No. & & Area & $\%$ \\
\hline 1 & Q5 & Measurement of risk and return & 11,9 \\
\hline 2 & Q6 & Asset allocation & 11,3 \\
\hline 3 & Q22 & Global markets and instruments & 9,0 \\
\hline 4 & Q20 & Financial risk management & 7,3 \\
\hline 5 & Q19 & Derivatives & 6,8 \\
\hline 6 & Q9 & Portfolio performance evaluation & 6,2 \\
\hline 7 & Q15 & Market efficiency & 6,2 \\
\hline 8 & Q2 & The investment process & 5,6 \\
\hline 9 & Q10 & Fundamental analysis & 5,6 \\
\hline 10 & Q23 & Retirement and pension funds & 5,6 \\
\hline & & Total & $\mathbf{7 5 , 5}$ \\
\hline
\end{tabular}

Academics regard the areas termed portfolio performance evaluation (Q9) and global markets and instruments (Q22) to be most in need of further research (table 4). On the other hand, practitioners regard the measurement of risk and return (Q5) and asset allocation (Q6) to be most in need of the attention of researchers (table 5). From a 
comparison of the top five areas ranked in table 4 with those ranked in table 5 , it is evident that four areas are regarded to be important areas for research by both the academics and the practitioners. These areas are measurement of risk and return (Q5); asset allocation (Q6); derivatives (Q19); and global markets and instruments (Q22). Academics ranked portfolio performance evaluation (Q9) as having the greatest need for research, but the practitioners ranked it in only the sixth position. On the other hand, the practitioners ranked financial risk management (Q20) in the fourth position in respect of need for research, whereas the academics ranked it in only the seventh position.

In a comparison of the top ten positions on both lists, there is general agreement between the academics and the practitioners in respect of the various areas, although the rankings of the two groups of respondents do differ. Market efficiency (Q15); fundamental analysis (Q10); and retirement and pension funds (Q23) are regarded to be important by both groups of respondents. The exceptions are that the academics regard the arbitrage pricing theory (Q8) to be important, whereas practitioners regard the investment process (Q2) to be important. As a result of these slight differences of opinion, hypothesis 6 , namely that academics and practitioners totally agree which areas need more research, cannot be accepted unconditionally.

\section{Areas in investment perceived to be in need of more attention than they are currently receiving?}

Hypothesis 7 states that practitioners believe that some areas deserve more attention than they are currently receiving in the training of South African investment specialists. In a separate question, that was addressed to the practitioners only, the respondents were request to list such areas, if they believed them to exist. An analysis of the results may be of value to the designers of courses for the training of investment practitioners. The focus is not primarily on the identification of the areas that are important (This issue was covered in table 3), but on the areas that practitioners believe should receive more emphasis than at present. Each respondent could list four areas. In total, 181 areas were listed. The ten areas that were regarded to be most in need of more attention in education are provided in table 6 . 
Table 6: Practitioners perception of the ten areas most in need of more attention in the training of investment specialists $(n=46)$

\begin{tabular}{|l|l|l|c|l|}
\hline No. & & Area & freq. & \multicolumn{1}{c|}{$\%$} \\
\hline 1 & Q5 & Measurement of risk and return & 20 & 11,0 \\
\hline 2 & Q6 & Asset allocation & 18 & 9,9 \\
\hline 3 & Q9 & Portfolio performance evaluation & 15 & 8,3 \\
\hline 4 & Q22 & Global markets and instruments & 13 & 7,2 \\
\hline 5 & Q10 & Fundamental analysis & 12 & 6,6 \\
\hline 6 & Q20 & Financial risk management & 11 & 6,1 \\
\hline 7 & Q15 & Market efficiency & 10 & 5,5 \\
\hline 8 & Q2 & The investment process & 10 & 5,5 \\
\hline 9 & Q14 & Financial statement analysis & 9 & 5,0 \\
\hline 10 & Q19 & Derivatives & 9 & 5,0 \\
\hline & & Total & & $\mathbf{7 0 , 1}$ \\
\hline
\end{tabular}

It is evident from an analysis of table 6 that only ten areas received $70,1 \%$ of the votes. The areas that were accorded the first five places (and that received $43,0 \%$ of the votes) were measurement of risk and return (Q5); asset allocation (Q6); portfolio performance evaluation (Q9); global markets and instruments (Q22); and fundamental analysis (Q10). If the list were extended to include the top ten areas, the following would be added: financial risk management (Q20); market efficiency (Q15); the investment process (Q2); financial statement analysis (Q14); and derivatives (Q19). Hypothesis 7, namely that there are areas that practitioners believe should receive more attention in investment education, must therefore be accepted.

\section{Conclusions and areas for further research}

This study indicates that some areas in investment are indeed perceived to be more important than other areas by both the academics and the practitioners concerned. These areas include asset allocation, fundamental analysis, and measurement of risk and return. The areas generally regarded to be the least important include arts, antiques and other hard assets; rights and capitalisation issues; and real estate. The areas that practitioners rated as being significantly more important than the academics did, include the financial system; sector and industry analysis; financial risk management; global markets and instruments; and retirement and pension funds. The areas that the academics rated as significantly more important than the practitioners did, include the Capital Asset Pricing Model and derivatives. 
There also appears to be agreement that the areas in need of research include measurement of risk and return; asset allocation; derivatives; and global markets and instruments. The areas that practitioners regard to be in need of more attention than they are currently receiving in the training of investment specialists include the measurement of risk and return; asset allocation; portfolio performance evaluation; global markets and instruments; and fundamental analysis.

The areas identified for further research include the ways in which the theories of investment management can be made more valuable for practitioners. An obvious example of this approach would be to investigate the areas that practitioners have identified as being in need of more research. Another would be to determine which analytical techniques practitioners have found to be most useful.

\section{Bibliography}

Bagrain, J.J. 1997. Knowledge utilization: The key management competency in the 21st century, Management Dynamics, Vol. 6, No. 4, pp.20-43.

Bodie, Z., Kane, A. and Marcus, A.J. 1993. Investments, 2nd edition, Irwin, Homewood, Illinois.

Bodie, Z., Kane, A. and Marcus, A.J. 2001. Essentials of Investments, 4th edition, McGraw-Hill, New York.

Bosch, J.K., Radder, L., Tait, M. and Venter, D.J.L. 1994. Empirical results with respect to educational needs in business economics, (Afrikaans), Management Dynamics, Vol. 3, No. 2. pp.17-38.

Brand, H.E. 1996. Educational challenges for management: Realities of higher education in South Africa and its implications for the training and provision of high level manpower, South African Journal of Management and Economic Sciences, Vol. 19, pp.81-99.

Brummer, L.M. and Rademeyer, W.F. (editors) 1982. Beleggingsbestuur, Van Schaik, Pretoria.

Charlton, W.T. 1998. Course tracking along professional designations: The chartered financial analyst track, Financial Practice and Education. Vol. 8, No. 1, pp.69-82.

Cooley, P.L. and Heck, J.L. 1996. Establishing benchmarks for teaching the undergraduate introductory course in financial management, Journal of Financial Education, Vol. 22, No. 2, pp.1-10. 
Davis, H.M. 1996. Dividends and finance professors have something in common: Irrelevance, Journal of Financial Education, Vol. 22, No. 1, pp.26-29.

Drucker, P.E. 1992. The new society of organizations, Harvard Business Review, Vol. 70, Nr. 5, pp.95-104.

Government Gazette. 1995. No.6290, 8 September 1995.

Hague, P. 1995. Questionnaire design and implementation, Kogan Page, London.

Jones, C.P. 2000. Investments: Analysis and Management, 7th edition, John Wiley, New York.

SAS INSTITUTE. 1985. SAS User's Guide, 5th edition, Cary, North Carolina.

SAQA, 1998. Criteria and guidelines for ETQA's, South African Qualifications Authority, Pretoria.

Simpson, G. 1997. Relevance in Financial education: A comprehensive approach worthy of Don Quixote, Journal of Financial Education, Vol. 23, No. 1, pp.34-40.

Van Rooyen, J.H. 1996. The education of students in financial risk management at the University of South Africa: An empirical view, (Afrikaans), Management Dynamics, Vol. 5, No. 3, pp.88-104.

Wolmarans, H.P. 1999. Financial management education: Is there a gap between academics and practitioners?, South African Journal of Management and Economic Sciences, (New series) Vol. 2, No. 3, pp.523-535. 